\title{
BURNING INTERNATIONAL BRIDGES, FUELLING GLOBAL DISCONTENT: THE UNITED STATES AND REJECTION OF THE KYOTO PROTOCOL
}

\author{
Christopher C Joyner*
}

This address was presented on 31 October 2001 by Professor Christopher C. Joyner as the 2001 Quentin Quentin-Baxter Memorial Lecture at the Victoria University of Wellington School of Law. Professor Joyner came to New Zealand as a Visiting Canterbury Fellow with the School of Law and Gateway Antarctica at the University of Canterbury from September through December 2001.

This paper tackles the controversy surrounding the rejection of the Kyoto Protocol by the United States of America. The paper's particular focus is the international effect of rejection. An updated epilogue discusses the result of the conclusion of the United Nation's Climate Change Convention, and the reaction of the United States.

It is a privilege for me to be here with you this evening to celebrate the contributions of Quentin Quentin-Baxter to international and constitutional law. Professor Quentin-Baxter was renown as a teacher of law--and I recognize several of his former students here with us tonight. I know of his reputation for being generous with his time and his knowledge with his students, as well as his deep sense of integrity and warm sense of humour. He was a teacher and scholar of international law of the highest repute. But perhaps even more than this, Professor Quentin-Baxter was a practitioner of the law. He loved the law, and the law lived not only through his words but also through his deeds. You should know that Professor Quentin-Baxter had a long and distinguished career in working to enforce and construct rules of international law. He assisted in the prosecution of war criminals at the International Military Tribunal at Tokyo, and thereafter joined the New

Professor of International Law and Government, Georgetown University, Washington, DC, USA; Visiting Canterbury Fellow, Gateway Antarctica and School of Law, University of Canterbury 
Zealand Ministry of Foreign Affairs. He participated in negotiating the 1949 Geneva Conventions on the Laws of War and the 1977 Geneva Protocols that amended them. He may in fact have been the only person to attend both these special negotiations that codified the modern laws of war. He was a member of the New Zealand delegation at the 1958 and 1960.

Geneva Conferences on the Law of the Sea, attended several annual sessions of the General Assembly of the United Nations, and served on the UN Commission on Human Rights. Professor Quentin-Baxter was elected for three terms to the UN International Law Commission and may well have been nominated and elected to the International Court of Justice had he lived longer. He also served as the constitutional advisor to Nive, and with his wife, Alison, (who served as the inspiration for "QB" and was a major contributor to his work) were principal constitutional advisors to the Marshall Islands. Both Professor and Mrs QB provided critical contributions in developing self government for these countries. In 1973, Professor Quentin-Baxter led the New Zealand team (consisting of Sir Kenneth Keith, Chris Beeby, Alison and himself) to the International Court of Justice to present the case against France for its atmospheric testing of nuclear weapons in the South Pacific. So, all this leads me to conclude, as my seventeen-year old son would say, that Professor Quentin-Baxter was "an awesome dude" with regard to his contributions to international law. And it is an honour for me to appear here in his name.

The timing of our discussions this evening is propitious. This past Monday, 29 October 2001, representatives from 160 countries convened in Marrakech, Morocco, to begin twelve days of talks intended for putting the final touches on the Kyoto Protocol to the 1992 UN Framework Climate Change Convention (UNFCCC). ${ }^{1}$ This protocol aims to limit humanity's influence on the climate by requiring cuts in gases linked to global warming. The main goal of the Marrakech meetings is to achieve sufficient consensus on the bracketed details so that the treaty can be ratified by enough governments to enable its enactment by the end of 2002, the tenth anniversary of the 1992 Rio Earth Summit. ${ }^{2}$

But proponents of enacting the Kyoto accord are hampered by two intervening circumstances. First, disagreements persist over how to measure gas reductions and levy

1 United Nations Framework Convention on Climate Change 9 May 1992 UN Doc. A/ I CONF.181/26, (1992) 1771 UNTS 107 reprinted in (1992) 21 ILM 849 [hereinafter cited as UNFCCC]; Report of the Conference of Parties on its Third Session Kyoto Protocol to the UN Framework Convention on Climate Change UN Doc FCCC/ I CP / 1997/7add1 reprinted in (1998) 37 ILM 22 [hereinafter Kyoto Protocol].

2 Arthur Max "Climate Meeting to Finalise Treaty" (28 October 2001) Washington Post (Washington DC) <http:/ / www.washingtonpost.com>; "Final Touches for Complex Treaty " 30 October 2001 The Press (Christchurch, New Zealand) 5. 
penalties on governments when they fail to comply with the target levels of emissions set for them. Many diplomats characterise this accord as the most complex international agreement ever negotiated, and ensuring compliance will be difficult at best. ${ }^{3}$ The second circumstance is even more troubling for me--the Bush Administration in the United States has rejected the Kyoto Protocol from being considered for ratification by the United States' Senate. ${ }^{4}$ This American response seems particularly problematic because the United States is the largest producer in the world-nearly twenty-five percent--of heat-trapping greenhouse gases that seriously aggravate the global warming situation. ${ }^{5}$

This fact brings me to the questions at the heart of tonight's discussion. Why is the United States so adamant in rejecting an international accord that practically all other governments are willing to embrace? Why did the world's most powerful country militarily, industrially, technologically, economically, politically, diplomatically — send a low-level delegation to Marrakech and take a silent, back seat in negotiations that could determine the fate of the world's climate in coming decades? ${ }^{6}$ And what are the prospects that this United States' recalcitrance might reverse itself in the near term future? These are the main issues that I would like to address this evening. But first, it helps to have an understanding of what the Kyoto Protocol actually purports to do.

The Kyoto Protocol to the 1992 Climate Change Convention was negotiated in December 1997 as an international framework instrument for reducing greenhouse gas emissions. ${ }^{7}$ The original protocol, which as of 1 November 2001 has not been ratified by

3 "Daily Coverage from COP-7" (Marrakesh, Morocco, 29 October - 9 November, 2001)" $<$ http:/ / www.iisd.ca/ climate/index.html> (last accessed 6 November 2001).

4 "Bush Firm over Kyoto Stance" (29 March 2001) CNN.com <http: / / www.cnn.com>.

5 Included as "greenhouse gases" in the Kyoto Protocol are carbon dioxide (CO2), methane (CH4), nitrous oxide (N2O), hydrofluorocarbons (HFCs), perfluorocarbons (PFCs), and sulphur hexafluoride (SF6). Kyoto Protocol, Annex A.

6 Andrew C Revkin "US is Taking a Back Seat in Latest Talks on Climate" (29 October 2001) New York Times <http: / / www.nytimes.com> (last accessed 29 October 2001).

7 The international political response to climate change took shape through the negotiation and adoption of the UNFCCC in 1992. This agreement sets out a framework for action intended to stabilise atmospheric concentrations of greenhouse gases at a level that would prevent humaninduced activities from leading to dangerous interference with the climate system. The UNFCCC entered into force on 24 March 1994. As of November 2001, 186 states have contracted to it as parties. United Nations, Status of Multilateral Treaties Deposited with the Secretary-General, <http://untreaty.un.org/ENGLISH/bible/englishinternetbible/partI/ChapterXXVII/treaty23.asp> (1 a st accessed 8 November 2001). 
the United States or, for that matter, by any other industrialised country, ${ }^{8}$ essentially requires developed countries (the so-called Annex I states) to reduce or limit emissions of greenhouse gases "at least 5 percent" below their 1990 levels of emissions during the period 2008-2012. ${ }^{9}$ It permits the use of "flexible mechanisms" to assist those countries in reaching their legally binding targets in a cost-effective manner. ${ }^{10}$ Such mechanisms include international emissions trading; ${ }^{11}$ joint implementation, which allows countries to receive credit for emission-reduction projects undertaken in other developed countries; ${ }^{12}$ and the clean development mechanism, which allows trading in certified emission reductions between industrialised and developing nations. ${ }^{13}$ Developing countries (non-Annex I States) contend they are excluded from these commitments, owing to their presently depressed levels of development and low contributions to greenhouse gas emissions in the past.

On 28 March 2001 President George W Bush reversed his 2000 election campaign pledge to legislate limits on $\mathrm{C} 02$ emissions from United States power plants, saying such a

8 United Nations, Status of Multilateral Treaties Deposited with the Secretary-General, $<$ http:/ / untreaty.un.org/ENGLISH/ bible/englishinternetbible/partI/ chapterXXVII/treaty24.asp> (last accessed 5 November 2001).

91997 Kyoto Protocol, art 3. In recognition of the fact that all developed countries have different economic circumstances and differing capacities to make emissions reductions, each developed country has a specific, differentiated target. The United States' requirement would limit the growth of its greenhouse gas emissions in the target period to 7 percent above 1990 levels. In addition, there are appended as Annex I states 39 countries, all of which are from North America, Europe, the former Soviet Union, as well as Australia, Japan, and New Zealand. No states are included in Annex I from Africa, Asia, Latin America, the Caribbean, or the Pacific. For the list of Annex I states, see below n 25.

101997 Kyoto Protocol, art 3, para 6.

111997 Kyoto Protocol, art 6. Under emissions trading, a party in Annex I "may transfer to, or acquire from, any other such Party emission reduction units resulting from projects aimed at reducing anthropogenic emissions by sources or enhancing anthropogenic removal by sinks of greenhouse gases" for the purpose of meeting its commitments under the treaty. Several provisos are attached, however, key of which is that such trading "shall be supplemental to domestic actions".

121997 Kyoto Protocol, art 4. Joint implementation refers to project-based activity in which one state can receive emission reduction credits when it funds a project in another country where the emissions are actually reduced.

131997 Kyoto Protocol, art 12. Under the "clean development mechanism", joint implementation between developed and developing countries would occur. Developed Annex I countries could contribute financially and non-Annex I countries could benefit from financing approved projects activities. Annex I countries could then use certified emission reductions from such projects to contribute to their compliance with part of their emission limitation commitment. 
rule would be too costly, in light of rising energy prices. ${ }^{14}$ He then announced that the United States would not implement the Kyoto Protocol on global warming. Given the current energy crisis, as well as "the incomplete state of scientific knowledge of the causes of, and solutions to global climate change and the lack of commercially available technologies for removing and storing carbon dioxide", the President asserted that he could not sign an agreement that would "harm our economy and hurt our workers". 15 President Bush also objected to the fact that the protocol—which had been ratified by only one of the states (Romania) necessary before it could go into effect-still "exempts 80 percent of the world...from compliance". ${ }^{16}$

In July 2001 the sixth Conference of the Parties to the UN Framework Convention on Climate Change (COP-6) resumed in Bonn, Germany. ${ }^{17}$ There agreement was reached without United States' participation concerning key political elements of the Protocol,

14 "Bush Firm over Kyoto Stance" (29 March 2001) CNN.com <http:/ / www.cnn.com> (last accessed 29 March 2001).

15 "Bush Firm over Kyoto Stance", above.

16 "Text of a letter from the President to Senators Hagel, Helms, Craig, and Roberts" The White House, Office of the Press Secretary (13 March 2001) <http:/ / www.whitehouse.gov/news/ releases/2001/03/20010314.html> (last accessed 13 March 2001).

17 Periodic meetings of the Conference of Parties have provided key fora for negotiating the Kyoto Protocol. In 1995, the Ad Hoc Group on the Berlin Mandate was established by COP-1 to reach agreement on what further steps should be taken to combat climate change. Following intense negotiations culminating in December 1997 at COP-3 in Kyoto, Japan, delegates agreed to a protocol to the UNFCCC that commits developed countries and counties in transition to a market economy to achieve quantified targets for decreasing their emissions of greenhouse gases. In November 1998, COP-4 convened in Buenos Aires, Argentina. There it adopted the Buenos Aires Plan of Action, which set out a schedule for reaching agreement on the operational details of the Protocol and for strengthening implementation of the UNFCCC. The critical deadline for resolving the package of still-problematic issues was set for two years, at COP-6. Between 25 October-4 November 1998, COP-5 met in Bonn, Germany, where it considered technical processes and mechanisms, such as the clean development mechanism, joint implementation, and the possibility of legally binding consequences for non-compliance of parties under the voluntary UNFCCC. In November 2000, COP-6 convened in The Hague, The Netherlands. High on its agenda was to reach agreement on several critical issues, among them capacity building and technology transfer; direction for financial response mechanisms; establishment of institutions; land use, land-use change and forestry; compliance policies and enforcement measures; and reporting of information. COP-6 was suspended when delegates failed to reach agreement. It reconvened, however, during 16-27 July 2001 in Bonn as COP 6-Part II. There the "political decision" as presented by the President of COP-6 Jan Pronk from The Netherlands was agreed to as the "Bonn Agreements". The high-level negotiations in Bonn conducted with the United States on the sidelines resulted in agreement on nearly all the main contentious issues, including use of carbon sinks, establishment of a compliance mechanism, and disallowing credit for nuclear facilities. 
including carbon sequestration and the decision to proceed with negotiating emissions trading and compliance procedures. ${ }^{18}$ The Bonn agreement amends the original Kyoto Protocol such that industrialised States are obligated to cut their output of greenhouse gases to an average of 5.2 percent below 1990 levels by $2012 .{ }^{19}$

The European powers were key drivers in getting the amended Kyoto accord approved by states around the world. ${ }^{20}$ The United States attended, but in the main did not participate in discussions related to key issues in the Protocol. Why is it that the United States, a country with less than five percent of the world's population, but which produces nearly twenty-five precent of the world's greenhouse gas emissions, was not willing to join 178 other governments in approving these changes to the Kyoto accord? Why is the Bush administration willing to touch off a firestorm of criticism from environmental activists at home and alienate allied governments abroad, especially in the European Union? In the intervening months, reasons for the Bush administration's opposition to the Kyoto accord have become evident as they crystallised into a hardened policy position.

At the outset, Kyoto critics contend that consensus is lacking, both in the United States and internationally, for the Protocol's underlying principles and policies. First, domestically strong reservations have been formally expressed in the United States Congress against the accord. In July 1997 the Senate unanimously passed (with a vote of 95-0) a resolution that affirmed that the body would not ratify any global climate treaty that would seriously harm the United States economy or that failed to require developing countries to reduce their emissions within the same time frame as developed countries. ${ }^{21}$

18 Matt Daily "World Reaches Climate Deal, Without US" (23 July 2001) abcNEWS.com $<$ http:/ / www.abcnews.com> (last accessed 23 July 2001); "Deal reached at climate talks" (23 July 2001) CNN.com/World <http:/ / www.cnn.com/no.ll/> (last accessed 23 July 2001).

19 Japan became a key player in these negotiations, since Prime Minister Junichiro Koizumi's government possessed the political leverage to make or break the treaty. Japan emerged from the negotiations with a package that permits it (and other states) to claim wide areas of its forest lands and farms as carbon-storing sinks to offset meeting its emissions reduction goals. "Global warming treaty agreed subject to ratification in 2002" 23 July 2001 (Reuters electronic version); "Deal reached at Climate talks", above.

20 "Deal Reached at Climate Talks, above.

21 The Byrd-Hagel Resolution (S RES 98) Report No 105-54 105 Congress 1st session (passed on 25 July 1997) BNA Daily Environment Report, 28 July 1997. ("The United States should not be a signatory to any protocol to, or other agreement regarding, the United Nations Framework Convention on Climate Change of 1992, at negotiations in Kyoto December 1997, or thereafter, which would ... mandate new commitments to limit or reduce greenhouse gas emissions for the Annex I parties (developed countries) unless the protocol or other agreement also mandates new specific scheduled commitments to limit or reduce greenhouse gas emissions for developing country parties within the same compliance period"). Despite such compelling Senate opposition, the Clinton administration signed the Kyoto Protocol on 12 November 1998. See the discussion in 
In United States constitutional law, the Senate is the legislative body responsible for ratifying international agreements, by a two-thirds majority. ${ }^{22}$ There is, in truth, no reason to expect that the Senate's view has softened in the interim years.

Second, at the international level, scant ratification activity has been forthcoming among developed states. As of November 2001, no member of the European Union has ratified the Protocol, nor have most other states. ${ }^{23}$ According to the United Nations secretariat, of the eighty-four states that have signed the Protocol, only forty-three developing countries-which will not be subject to its emissions targets--and Romania have ratified it. ${ }^{24}$ No major Annex I state has done so. Romania, which is an Annex I State, ratified the Kyoto Protocol on 19 March 2001. Even so, as the United Nations Framework Convention on Climate Change reports, Romania represents only 1.2 percent of the combined emissions (ie, 55 percent) required to bring the Protocol into force. ${ }^{25}$

Respective to the Kyoto accord itself, opponents argue that it is a scientifically flawed document for dealing with global temperature changes and their impacts on the environment. Generally they believe that considerable uncertainty surrounds the science of climate change and humankind's contribution to global warming. More specifically, the Bush administration charges that three critical considerations militate against United States support of the Kyoto Protocol: (1) the Protocol is unachievable; (2) the Protocol is unfair; and (3) the Protocol is economically harmful to the United States.

Susan R Fletcher, "Global Climate Change: The Kyoto Protocol" Congressional Research Service, CRS Report for Congress No RL30692, 28 September 2000.

22 United States Constitution, art 2, s 2.

23 United Nations, Status of Multilateral Treaties Deposited with the Secretary-General, $<$ http:/ / untreaty.un.org/ENGLISH/bible/englishinternetbible/partI/ chapterXXVII/ treaty24.asp> (last accessed 5 November 2001)

241997 Kyoto Protocol, art 3. In recognition of the fact that all developed countries have different economic circumstances and differing capacities to make emissions reductions, each developed country has a specific, differentiated target. The United States' requirement would limit the growth of its greenhouse gas emissions in the target period to 7 percent above 1990 levels. In addition, there are appended as Annex I states 39 countries, all of which are from North America, Europe, the former Soviet Union, as well as Australia, Japan, and New Zealand. No states are included in Annex I from Africa, Asia, Latin America, the Caribbean, or the Pacific. For the list of Annex I states, see below n 25.

25 See Kyoto Protocol, Annex B. The so-called "Annex I states" that will be bound to the emissions targets are enumerated in Annex B of the Kyoto Protocol and include the following countries: Australia, Austria, Belgium, Bulgaria, Canada, Croatia, Czech Republic, Denmark, Estonia, European Community, Finland, France, Germany, Greece, Hungary, Iceland, Ireland, Italy, Japan, Latvia, Liechtenstein, Lithuania, Luxembourg, Monaco, the Netherlands, New Zealand, Norway, Poland, Portugal, Romania, Russia, Slovakia, Slovenia, Spain, Sweden, Switzerland, Ukraine, the United Kingdom, and the United States. 
First, the Protocol is unachievable. Critics contend that the Protocol is fundamentally flawed. That is, the accord is predicated on faulty science, the goals of which cannot be attained. Considerable uncertainty remains about the science of climate change and humankind's contribution to the problem. The critics' main target here is the United Nations' Intergovernmental Panel on Climate Change (IPCC) $)^{26}$ and the assessment reports that it produces every five years. These assessment reports, which become central to the debate over global warming, purport to represent a consensus of what is known, what is still uncertain, and how various actions might cause changes in future climate conditions. The Second Assessment Report predicted in 1995, for example, that temperature increases by the year 2100 could range from less than two degrees $F$ to more than six degrees $F$. This prediction notwithstanding, conservative scientists point out that the report concedes

26 The Intergovernmental Panel of Climate Change was established in 1988 by the UN Environmental Programme and the World Meteorological Organization to assess the condition of the existing knowledge about the climate system and climate change. Comprised of 1500 of the world's leading scientists, the IPCC evaluates the environmental and socio-economic impacts of climate change and formulates response strategies through its regular reports. The IPCC's First Assessment Report, completed in August 1990, confirmed the scientific basis for climate change and served as the scientific foundation for negotiating the UN Framework Convention on Climate Change. The Second Assessment Report, issued in 1996, concluded that human activities were not just a possible cause, but were a likely cause for climate change, a much stronger conclusion than that proffered in the 1990 report. The third and most recent Assessment Report was issued in January 2001 and contains calculations projecting the range of temperature increases during the 21st century. The Reports are available on line at: $<$ http://www.ipcc.ch/>.

The IPCC is organized into three working groups. Working Group I is concerned with the science of climate change, in particular developments in the scientific understanding of past and present climate, climate variability, climate predictability and climate change; progress in the modelling and projection of global and regional climate and sea level change; observations of climate, including past climates, and assessment of trends and anomalies; and gaps and uncertainties in current knowledge. Working Group II concentrates on climate change's impact on ecosystems, their vulnerability and their need for adaptation. This includes assessing the effects of climate change on forests, rangelands, deserts, mountains, non-tidal wetlands, coastal zones, small islands, freshwater ecology, wood production, fisheries, financial services, and human health. Working Group III examines the mitigation of climate change, specifically by conducting technical assessments of the social and economic impacts of climate change on both regional and global levels. Among the activities of Working Group III are assessments of social and economic costs and benefits of response actions; determination of economic and social benefits of limiting greenhouse gas emissions and enhancing sinks; assessing the economic, social and environmental costs of mitigating greenhouse gas emissions; ascertaining what mitigation and adaptation responses options are available; and assessment of the economic viability of policy instruments to arrest climate change. For contributions of each IPCC Working Group to the Third Assessment Report, see <http:/ / www.rivm.nl/env/int/ipcc/>. 
"current data and systems are inadequate for the complete description of climate change", 27 thus undermining the very scientific credibility that it purports to present.

In January 2001, in its Summary for Policymakers for the Third Assessment Report, ${ }^{28}$ the IPCC predicted the onslaught of coastal floods, increasingly violent weather, more droughts, increased spread of mosquito-borne diseases, crop failures, and other catastrophes. It places blame on human activities for temperatures warming at a rate faster than previously forecast. ${ }^{29}$ While the media characterises the summary as having a higher degree of certainty that previous assessments, ${ }^{30}$ the Bush administration and conservative critics point to independent reviews that find the IPCC document to be a flagrant misrepresentation of what is known about the impact of future climate changes. ${ }^{31}$ Why should these IPCC assessments be considered so defective and wrongheaded? Critics allege that they present speculation as fact. That is, predictions are made on the basis of simple models that fail to take into account current or historical climate phenomena. Moreover, they fail to replicate fundamental climate processes. These reports project the appearance of certainty in the absence of substantiated scientific evidence. In addition, the IPPC reports are accused of failing to distinguish between nonhuman and human-caused factors that might contribute to climate change, as well as basing their predictions on worst case scenarios that suggest higher range of potential warming and sea level rise by 2100 . The critics assert that no scientifically-sound consensus exists as to whether global warming is real, much less the extent which human activities actually contribute to it. ${ }^{32}$

27 John T Houghton and others (ed) Climate Change 1995: The Science of Climate Change Contribution of Working Group I to the Second Assessment Report of the Intergovernmental Panel on Climate Change (Cambridge University Press, 1996) 411.

28 Available on line at: <http:// www.rivm.nl/env/int/ipcc/images/wgI_spm.pdf > .

29 Press release, "New UN Global Warming Report is Not New-Predictions Derived from ExtremeWorst-Case 'Future Scenarios'" (27 February 2001) RPPI Rapid Response No 101, 1, <http:/ / www.rppi.org/0123a.01.html> (1.ast accessed 27 February 2001); also see, Green "Newest IPCC Report on Global Warming Fails to Deliver Sound Policymaking Models" (21 January 2001) Reason Public Policy Institute, <http:/ / www.rppi.org/rr101.html> (last accessed 27 April 2001).

30 Houlder "Urgent Warning on Global Warming" (21 January 2001) Financial Times New York.

31 Wojick "The UN IPCC's Artful Bias: Glaring Omissions, False Confidence and Misleading Statistics in the Summary for Policymakers" $<$ http://www.vision.net.au/ daly/guests/un_ipcc.htm> (last accessed 20 November 2001); Green, above.

32 Green, above, 3-5. According to Kenneth Green, Director of the Environmental Program at the Reason Public Policy Institute, the IPCC Report's predictions are based on simple models that are not calibrated to observed climate phenomena, fail to emulate fundamental climatic processes, and present the appearance of certainty that is unsupported by evidence in technical reports and studies published in mainstream scientific journals. 
Another fallacy of the Kyoto Protocol, according to conservative critics, is the unrealistic targets that are presented for mandatory emissions reductions. To meet the Protocol's objectives of five percent reductions without imposing excessive carbon taxes or protracted emissions trading, calculations suggest that American and European societies would have to reduce their greenhouse gas emissions by thirty percent by $2010 .{ }^{33}$ The plain fact of the matter, assert Kyoto opponents, is that this goal cannot be attained. With respect to being unachievable, a final point is made that the Kyoto accord contains misdirected objectives. Conservative critics complain that too much focus is placed by the media on the impacts carbon dioxide has on global warming. Climate change, they contend, should be addressed more practically by reducing the greenhouse gases such as methane and ozone, as well as soot and aerosols. ${ }^{34}$ These are the key arguments underlying the first charge by critics in the Bush administration-that the Kyoto Protocol is unachievable-since the argument is based on bad science that cannot be implemented as policy.

A second fundamental criticism by the Bush administration is that the Kyoto Protocol is unfair. This is because the instrument exempts developing countries (ie, non-Annex I States)-including China, India and Brazil--from its binding emissions reductions. ${ }^{35}$ Critics are quick to point out, however, that because of population increases, economic expansion, and increasing reliance on commercial fuels, developing countries will emit more greenhouse gases within 15 years than the major industrialised States. ${ }^{36}$ More recent data

33 Mary H Novak "The Kyoto Protocol: Can Annex B Countries meet their Commitments?" American Council for Capital Formation Center for Policy Research Special Report October 1999, 27. Novak also asserts the EU would have to reduce its emissions by 2010 from 16 percent to 30 percent.

34 James Hansen and others, "Global Warming in the 21st Century: An Alternative Scenario" Proceedings of the National Academy of Sciences (29 August 2000). On Hansen's study, the Washington Post editorialised that it serves to "remind us that climate issues are complex, far from fully understood and open to a variety of approaches. It should serve as a caution to environmentalists so certain of their position that they're willing to advocate radical approaches, no matter what the economic cost". "Hot News on Warming" (28 August 2000) Washington Post, A18.

35 The official view articulated at the Third Conference of Parties on 1-10 December 1997 contains the assertion that developing countries, regardless of their levels of economic development or emissions of greenhouse gases", are not required to take any specific steps to reduce or limit emissions. For example, China, Brazil, South Korea and India are 'Developing Countries' for purposes of the Treaty". See "Understanding the Berlin Mandate", I Global Climate Negotiations Materials 19 November 1997. In addition, the inference can be drawn that these states are not listed among the Annex B countries required to limit emissions, they are not bound to take those steps to limit their emissions of greenhouse gases.

36 Mary Novak "Global Climate Change Policies: The Impact on Economic Growth, United States Consumers, and Environmental Quality" American Council for Capital Formation Center for Policy Research, Special Report (October 1997) 8. 
from the Energy Information Administration of the United States Department of Energy predict that by 2020, total carbon dioxide emissions by developing countries will significantly surpass those of industrialised countries. ${ }^{37}$ Moreover, world coal use is projected to grow by thirty percent between 1999 and 2020, with China and India alone accounting for ninety percent of that increase. ${ }^{38}$

Since greenhouse gases are not stationary, conservative commentators maintain that failing to include developing counties in the reduction goals will negate any reductions that industrialised countries might achieve. ${ }^{39}$ In fact, global emissions would increase, as energy-intensive production would transfer from developed to underdeveloped countries where energy use is less costly. Exempting developing countries from legally-binding emissions targets, the critics assert, will create a competitive disparity between industrial states and developing countries, ${ }^{40}$ clearly to the industrial states' great disadvantage. The Bush administration (and the United States Senate) believes that if the goal of the Kyoto Protocol is to reduce greenhouse gas emissions collectively given the alleged risk of global warming, then developing countries must be made subject to the Protocol's restrictions. Put bluntly, omitting these states from emissions restrictions undercuts the Protocol's potential for bringing about permanent reduction of greenhouse gas emissions.

A third reason the Bush administration opposes the Kyoto Protocol rests on the presumption that its policies will impose severe economic consequences on the United States. That is, critics believe that the reduction of greenhouse gas emissions through this legal mechanism will generate adverse economic repercussions for United States industry and the American consumer. Frequently cited to uphold this allegation are studies published by private conservative think tanks, such as that by Margo Thorning done in December 2000 for the

37 United States Department of Energy, Energy Information Administration, International Energy Outlook 2001 Appendix B, Table A-10. <http:/ / www.eia.doe.gov/ oiaf/ieo/index.html>.

By 2020, the United States and Canada will account for 16.4 percent and Western Europe will account for 11.5 percent of the metric tons of carbon equivalent produced. Developing Asia will account for 30.9 percent. Table A-10, above. Over the next two decades, the United States DOE projects that the United States will produce CO2 emissions equivalent to 2,193 million metric tons of carbon, while China, India, and Brazil combined will produce CO2 emission amounting to 2903 million tons of carbon equivalent because of increased coal use. In 2020 China alone will produce 2,059 million metric tons equivalent.

38 Department of Energy International Energy Outlook 2001, above, 12.

39 Angela Antonelli "Road to the Hague: A Desperate Effort to Salvage a Flawed Climate Change Treaty" Heritage Foundation Backgrounder No 1401 (17 November 2000) 8.

40 Mary Novak "Global Climate Change Policies: The Impact on Economic Growth, United States Consumers, and Environmental Quality" American Council for Capital Formation Center for Policy Research, Special Report (October 1997) 5. 
American Council for Capital Formation Center for Policy Research. ${ }^{41}$ According to the calculations produced in this study, productivity in the United States following implementation of the Protocol would fall some US $\$ 120$ billion to $\$ 400$ billion between 2001 and $2010 .{ }^{42}$ If required emissions reductions were achieved domestically, by 2010, the gross domestic product lost per household in the United States would range between US $\$ 1950$ to $\$ 3750 .{ }^{43}$ Concomitant with these reductions in standard of living in the United States would come the acceleration in economic growth in developing countries, thus disadvantaging the United States economy even further.

The Thorning study predicts that by 2020, increases in prices for gasoline would range from about thirty percent to over fifty percent and increases in prices of electricity would run from fifty percent to over eighty percent. In addition, workers could suffer decreases in wage growth of five percent to ten percent per annum, while living standards would drop by fifteen percent. ${ }^{44}$ Employment losses would be similarly significant. According to another critical economic analysis, if all mandated carbon emissions targets are achieved domestically, every state in the United States will incur losses in employment. Total job losses are put at 2.4 million, with low- and moderate-income families being most severely affected. ${ }^{45}$

American competitiveness is believed to be at risk as well. Developing countries would not need to raise their energy or product prices, as would the industrial countries after implementing the mandated steps to meet their target greenhouse emission levels. ${ }^{46}$ If the Kyoto Protocol's emissions limits are implemented, energy prices in various United States industrial sectors can be expected to rise, though to varying degrees. The cost of electricity could climb as much as eighty-five percent, while gasoline prices would rise fifty-five percent, and the rate for natural gas might soar as much as 120 percent. ${ }^{47}$ Correspondingly, United States output of energy-intensive products, such as automobiles, steel, paper, and

41 Margo Thorning "A United States Perspective on the Economic Impact of Climate Change Policy" American Council for Capital Formation Center for Policy Research, Special Report (December 2000).

42 Thorning, above, 2. See also Global Climate Coalition, Economics Committee "The Impacts of the Kyoto Protocol" 3 (May 2000) <http:/ / www.globalclimate.org> (hereinafter cited as Impacts of Kyoto Protocol).

43 Impacts of Kyoto Protocol, above, 3.

44 Thorning, above, 4.

45 Impacts of Kyoto Protocol, above n 42, 3. The United States Energy Information Agency estimates that the Kyoto Protocol might cost 1.2 million jobs.

46 Thorning, above, 5.

47 Impacts of Kyoto Protocol, above, 4 (table of data extrapolated from EIA 1990 and WEPA studies). 
petrochemicals, could decline as much as fifteen percent by $2020 .{ }^{48}$ Rising energy costs are projected as adversely affecting American agriculture as well, causing declines in United States food exports and requiring increases in food imports.

United States government officials are, of course, politicians. They can thus neither tolerate nor accept such negative economic consequences given that those conditions would redound to their political detriment and likely encourage their constituents to remove them from office in the next general election. Taking the lead in lobbying against the Kyoto Protocol--the adoption of which is depicted as transforming these hypothetical calculations into hard economic reality--is the Global Climate Coalition (GCC). ${ }^{49}$ Comprised of oil companies, auto makers, electric utilities, and other industrial concerns, the GCC is a special lobby group that contends insufficient data and evidence are available to determine conclusively that global warming is a genuine phenomenon. Until more information is available and definitive evidence is in, the GCC maintains that the United States government should take no serious policy action that might impede United States economic progress. Over the past year, the GCC has emerged as a strong voice arguing against the Protocol. It has launched nation-wide media campaigns on television, in newspapers and in weekly periodicals. It undertakes lobbying efforts in Congress to persuade both Senators and members of the House of Representatives that the Kyoto Protocol runs counter to the United States' national interest-economically, politically, legally, and commercially. The GCC commissions private studies and sponsors special reports. These are put forward to demonstrate the economic flaws and commercial fallacies of the United States adopting an international instrument that not only impedes its own domestic growth, ${ }^{50}$ but also permits developing countries to industrialize with their greenhouse gas pollution unchecked. The message of the GCC comes though loud and clear, and it is being heard by the Bush administration: The United States cannot

48 Thorning, above, 5.

49 The Global Climate Coalition is an organization of trade associations established in 1989 to coordinate business participation in the international policy debate on the issue of global climate change and global warming. For the GCC's homepage, see <http:/ / www.globalclimate.org >

50 See generally Impacts of Kyoto Protocol, above, which extrapolates data from four studies: United States Department of Energy, Energy Information Administration, Impacts of the Kyoto Protocol on US Energy Markets and Economic Activity (October 1998); WEFA Inc, Global Warming; The High Cost of the Kyoto Protocol, National and State Impacts, 1998; Standard \& Poor's DRI, The Impact of Meeting the Kyoto Protocol on Energy Markets and the Economy, July 1998; and Charles River Associates, The Post-Kyoto Climate-Impacts on the US Economy, January 1999. 
afford the high economic, social, and political price of the Kyoto accord, and its government should not be asked to pay for it. ${ }^{51}$

Notwithstanding the official view of the United States position opposing the Kyoto accord, several recent developments give pause for reflection on the reality of global warming and what role the United States should play in remedying that condition. Despite conservative critics' assertions, consider the following points.

1. It is true that carbon cycling of $\mathrm{CO}_{2}$ from naturally occurring processes through the biosphere each year is enormous-as much as 800 billion tons-based on scientific calculations from ice cores going back 10,000 years ago. ${ }^{52}$ But it is also true that human activities since the Industrial Revolution began in 1850 now generate some 24 billion tons of $\mathrm{CO}_{2}$ per year into the atmosphere. One half of this amount is absorbed by forests and the oceans. But conclusive scientific evidence suggests that atmospheric concentrations of $\mathrm{CO}_{2}$ are around thirty-two percent higher than they were 150 years ago. ${ }^{53}$

2. The most recent projections of state-of-the-art computer models of the Earth's climate project a globally-averaged warming from nearly three to 10.7 degrees F over the next 100 years, if greenhouse gases continue to accumulate in the atmosphere at current rates. Many climate scientists believe that such a warming could shift temperature zones, rainfall patterns, and agricultural belts, and under certain scenarios, cause sea levels to rise. They further predict that global warming could produce far-reaching effects-some positive, some negative, depending on how it is experienced in a region-on natural resources; local ecosystems; food production; energy supply, use and distribution; transportation; land use; water supply and its management; and human health. ${ }^{54}$

3. Researchers in a United States government agency, the National Oceanic and Atmospheric Administration (NOAA), reported in 2000 that the twelve warmest years (when globally averaged) since historical records have been kept (ie 1860) occurred in the past two decades, with 1990 and 1998 being the warmest. ${ }^{55}$ Some of this warming, they

51 On the GCC's position on climate debate, see <http://www.globalclimate.org/climdebate.htm>. Cf President Bush's policy statement, "Action on Climate Change Review Initiatives" The White House 13 July 2001, <http:// state.gov/g/oes/climate/index.cfm?docid=4101> (last accessed 20 November 2001).

52 John R Justus \& Susan R Fletcher "Global Climate Change" CRS Issue Brief for Congress updated 13 August 2001 (Congressional Research Service 2001) CRS-2.

53 Justus \& Fletcher, above, CRS-2.

54 See generally the IPCC, above.

55 MacCracken, and others, "Scenarios for Climate Variability and Change", in National Synthesis Team, United States Global Change Research Program, Climate Change Impacts on the United States: The Potential Consequences of Climate Variability and Change (2000) 23. 
conclude, is human-induced, although indirect measurement methods through satellite instruments have not been able to demonstrate clear, positive trends in this regard.

4. The most recent report by the Intergovernmental Panel on Climate Change concludes that firmer links have been established between human activities and climate temperatures. It bears reiterating that this IPCC report suggests a higher range of potential warming can be expected over the next century-perhaps as much as ten degrees $\mathrm{F}$. Notwithstanding criticisms by conservative commentators, the IPCC is generally respected worldwide as a legitimate scientific body set up to assess the scientific, technical and economic information relevant for understanding the risks associated with humaninduced climate change.

5. Finally, on 6 June 2001 a Committee on the Science of Climate Change of the United States National Research Council (NRC) released a report, Climate Change Science: An Analysis of Some key Questions, which posited that global warming could well produce serious societal and ecological impacts by the end of the twenty-first century. ${ }^{56}$ This report, which was commissioned by the Bush White House and prepared by eleven of the leading climate scientists in the United States, summarizes the present state of knowledge on climate change and confirms that the climate changes observed during the past several decades were most likely due to human activities. ${ }^{57}$ The committee members warned, however, that the possibility could not be ruled out that the climate's natural variability might be responsible for a significant portion of that trend. The report goes on to assert that human-induced warming and sea-level rise were expected to continue throughout the twenty-first century and beyond, but they stressed that given "the considerable uncertainty in current understanding of how the climate system varies naturally and reacts to emissions of greenhouse gases and aerosols, current estimates of the magnitude of future warming should be regarded as tentative and subject to future adjustments (either upward or downward)". ${ }^{58}$ Significantly, the NRC report generally concurred with the conclusions of the IPCC in its January 2001 report, which found that the Earth warmed by about one degree F during the twentieth century, and that most of the warming over the past fifty years can be attributed to the build-up of greenhouse gas concentrations in the atmosphere. ${ }^{59}$

56 Committee for the Science of Climate Change of the United States National Research Council, Climate Change Science: An Analysis of Some Key Questions (2001), $<$ http:/ / books.nap.edu/html/ climatechange/> (last accessed 20 November 2001).

57 Climate Change Science, above, 1 (Summary).

58 Climate Change Science, above, 1 (Summary).

59 Climate Change Science, above, 1 (Summary). The National Research Council also concurred with the IPCC's prediction that an average increase of 5.4 degrees $\mathrm{F}$ ( 3 degrees $\mathrm{C}$ ) temperature by the 
So what are we to make of all of this? How much global warming is actually occurring? What is causing it? How fast is it happening? How real is the human-induced climate change threat? What remedial actions are necessary, on how great a scale?

There are no definitive answers to these critical queries. My own views support the United States adopting the precautionary principle of international environmental law, ${ }^{60}$ driven by the newer principle of "common but differentiated responsibility". 61 The international community, inclusive of the United States, should take a number of anticipatory, but flexible policy responses, much like purchasing an insurance policy to hedge against the possible risks associated with potential climate changes in the future. It is easy to say that we need more time to study and research whether the problem exists and if so, to determine the extent to which it exists. But if global climate change is real--and considerable scientific evidence already is available to suggest that it is--then time is precious, particularly when one considers the possible fate of low-lying island states in the Pacific and Indian Oceans as those sea levels continue to rise. ${ }^{62}$

end of the 21st century will be "consistent with the assumptions about how clouds and atmosphere relative humidity will react to global warming". Climate Change Science, above n 56, 1 (Summary).

60 The precautionary approach advocates that governments should not use the fact that absolute scientific certainty regarding the adverse environmental effects of activities to postpone putting in place measures to prevent those effects. This strategy requires that risk avoidance becomes an established decision norm, ie that in the face of risks and scientific uncertainties, we must act as if there were complete scientific certainty. See Prue Taylor, An Ecological Approach to International Law: Responding to Challenges of Climate Change (Rutledge, New York, 1998), chapters 2 and 3; Timothy O'Riordan \& James Cameron (eds) Interpreting the Precautionary Principle (Cameron May, London, 1994); Hughes "The Status of the Precautionary Principle in Law" (1995) 7 J Environmental Law 224; O'Riordan and Jordan "The Precautionary Principle in Contemporary Environmental Policies" (1995) 4 Environmental Values 191.

61 "Common but differentiated responsibility" refers to the principle in articles 3 and 4 of the UNFCCC in which industrialised developed states take the lead in addressing the climate problem, specifically by excluding developing countries from binding greenhouse gas emissions reductions. The principle is rooted in shared notions of fairness, that is, the developed countries are disproportionately responsible for historical greenhouse gas emissions and have the greatest capacity to act. Indeed, the preamble to the UNFCCC affirms that "the largest share of historical and current global emissions of greenhouse gases has originated in developed countries". UNFCCC above n. 1, pmbl. For discussion see Harris, "Common but Differentiated Reasonability: The Kyoto Protocol and United States Policy", (1999) 7 NYU Environmental L J 27; Borione \& Ripert "Exercising Common but Differentiated Responsibility", in Irving M Mintzer \& J Amber Leonard (eds) Negotiating Climate Change; The Inside Story of the Rio Convention (Cambridge University Press, New York, 1994); and Sands "The 'Greening' of International Law: Emerging Principles and Rules" (1994) 1 Indiana J Global Legal Studies 293, 295-96.

62 In this regard, it is worth noting that since 1995 the Antarctic ice shelves have demonstrated greater instability since scientific observations have been made during the twentieth century. In 
As the UNFCCC parties met in Marrakech, the remaining details making the COP-6 decisions operational were finalised. It remains to be seen just how successful the Kyoto signatories will be in ratifying the Kyoto Protocol and reaching the threshold for it to enter into force without the United States. At the very least, even if all the Annex I States were to ratify the accord, and it entered into force, the collective five percent reduction in emissions that is the Protocol's goal will be difficult to attain without the United States, which emits nearly one quarter of all the world's greenhouse gases.

It seems to me that the practical and responsible policy position of both the Bush administration and United States corporations is to accept the science of global climate change, establish domestic greenhouse gas emission targets, and enforce policy measures that can meet them. A change in attitude by the American government is also necessary. The Kyoto Protocol should be viewed as a first, albeit incomplete, step toward addressing the issue of global warming internationally. Moreover, the Bush administration should strive to realize that dealing with climate change can be made compatible with sustained economic growth in the United States. The Kyoto Protocol should be viewed as an opportunity for, not as a penalty on, the United States' economy. New technologies for reducing emissions can correct the industrial sins of the past and present; new non-fossil fuel forms of energy must be developed; and innovative means should be created for recycling carbon dioxide from airborne industrial wastes to more constructive land-based uses. All these new technologies can contribute to sustained economic growth in the United States, while curtailing American's output of noxious greenhouse gas emissions.

Lessons for United States policy as it relates to global warming can be drawn from the tragic events of 11 September. The terrorist bombings of the World Trade Center in New York City and the Pentagon in Washington, DC make clear that the United States, and in fact the entire world community, have entered a new era--one in which national security depends on extensive and intensive collaboration with other states. No country can be an island unto itself. We live in an interdependent and globalised international economy, in

1995, a piece of the Larsen Ice Shelf the size of the United States state of Rhode Island and 500 feet thick broke off the continent, one of the largest shelf collapses on record. Stevens "Catastrophic Melting of Ice Sheet Is Possible, Studies Hint" (7 July 1998) New York Times; Woodward "Antarctic Glacial Meltdown" (28 December 1998) San Francisco Chronicle 1. In 1998 satellite photos revealed that the Larsen B ice shelf continued to crumble, losing nearly 2000 more square miles of area, while the Wilkins Ice Shelf lost nearly 500 square miles. "Global Warming Sharply Reduces Antarctic Ice Shelves" (9 April 1999) Baltimore Sun 28A. In March 2000, a huge iceberg 170 miles long by 25 miles wide (274 kilometres by 40 kilometres) and weighing an estimated 2 billion tons, broke off the Ross Ice Shelf. The 4,250 square mile area of this "Godzilla" berg, known as "B-15", was nearly as large as the United States state of Connecticut before it broke up into five pieces. See Onion "Scientists Seek Explanations for Antarctic Icebergs" (5 October 2000) ABC News Internet Ventures, <http://www.climateark.org/articles/2000/4th/crackinu.htm> (last accessed 19 November 2001). 
which every state is being constantly penetrated and bombarded by forces, persons and technologies from dozens of other states. Speaking as an American, the United States in particular and western governments in general have no hope of stopping terrorists if we try to mange the problem alone. The same is profoundly true of global warming and climate change. The events of 11 September boldly remind us that strong collaboration and cooperation with other governments are critical—not just for dealing with hateful extremists, but also for tackling the range of serious global problems that transcend the national control of any single state, even a world "superpower". This suggests the need for a new partnership in the world, one in which many governments, including the United States, join forces with each other to deal with shared challenges, through shared responses. Many problems today are global in scope and generate worldwide ramifications, whether they be global warming, nuclear proliferation, oceans pollution, the transmission of infectious diseases, unstable financial markets, massive poverty or the deprivation of human rights. Global problems demand global solutions, which can only be accomplished by governments, especially the Great Powers, working together.

By focusing on the costs of cooperation, the Bush administration ignores the costs of refusing to cooperate. In international problem solving, reciprocity matters. If the United States refuses to work with rest of the world to manage global warming and other issues that matter to its friends, it should not be surprised when those allies decline to cooperate with the United States on issues that matter to the United States. Pursing the policy of the free hand-that is, adopting policies that minimise constraints on the United States' ability to conduct its foreign policy in a way that seems in its best national interest at that moment-is dangerous. While unilateralism might appear politically expedient, it generates political resentment and legal alienation. Such an isolated America will be a less secure America. That is something none of us can afford.

In this regard, the American people and the Bush administration will find it valuable to reflect upon the words of one of New Zealand's most eminent public lawyers. He wrote of constitutions as being organic documents in society. In my estimation, the same can be said for core treaties and other binding international legal agreements. They too are born, they live, evolve, change, and then they die. As an international lawmaking treaty, the 1992 Climate Change Convention and its Kyoto Protocol take on the character of organic legal instruments. They resemble a constitution among the international community for governing global warming. In writing of constitutions (but for our purposes, keeping in mind the context of international conventions), this New Zealand legal scholar eloquently posited: 63

63 Quentin Quentin-Baxter "The Governor-General's Constitutional Discretions: An Essay towards a Re-definition" (1980) 10 VUWLR 289, 290. 
A constitution is a human habitation. Like a city, it may preserve its life and beauty through centuries of change. It may, on the other hand, become either a glorious ruin from which life has departed or a dilapidated slum that not longer knows the great tradition of its builders. Constitutions, like ancient buildings, need the care and protection of an historic places trust, to draw attention to the weaknesses in the fabric and to suggest how present needs can be met without sacrificing the inspiration of the past. They also need an enlightened and interested general public, with a strong collective feeling about the difference between a folly and a landmark of enduring significance.

These are the words of Professor Quentin Quentin-Baxter, written in 1980. But they hold special meaning today for international lawmaking treaties in general and the Kyoto accord in particular. For indeed, the Kyoto Protocol needs an enlightened and interested general public to succeed, and its creation must be guided by a strong collective feeling that global warming should be controlled if that agreement is to attain the status of enduring significance. To do otherwise is to affirm the current selfishness and myopia of the United States government, which seems destined to be folly, both for arresting global climate change and for ensuring the well being of the Earth's environment for future generations.

\section{EPILOGUE}

On 9 November 2001, 160 parties to the United Nation's Climate Change Convention meeting in Marrakech concluded their negotiations on finalising operational details for the Kyoto Protocol, which opened the way for that instrument's widespread ratification and eventual entry into force. The Protocol will enter into force and become legally binding after its ratification by at least fifty-five parties to the UNFCCC, including industrialised countries representing at least fifty-five percent of the total 1990 carbon dioxide emissions from that group. One government has already asserted that it will not be among them: the United States. ${ }^{64}$

Intentional inaction by the United States at Marrakech reveals the Bush administration's persistent intransigence on rejecting the Kyoto Protocol. While the United States did not block conference consensus in adopting the rules, the Bush administration did assert in its closing statement that the Kyoto Protocol is not sound policy, and posited four key reasons for that conclusion. First, the Protocol's emissions targets "are not scientifically based or environmentally effective, given the global nature of greenhouses gas emissions and the Protocol's exclusion of developing countries from its emissions

64 As of 10 July 2002, 74 parties, including all of the European Community, have ratified the Kyoto instrument. Kyoto Protocol to the United Nations Framework Convention on Climate Change, in Multilateral Treaties deposited with the Secretary-General <http:/ / untreaty.un.org/ENGLISH/bible/ englishinternetbible/ partI/ chapterXXVII/ treaty25.asp> (last accessed on 10 July 2002). 
limitation requirements, as well as its failure to address black soot and tropospheric ozone". Second, the Protocol creates an element unacceptable to the United States, namely, "an institution to assess compliance with emissions targets that is dominated by developing country members without targets". Third, the protocol gives "[m]ore favourable treatment for parties operating within a regional economic organization [namely, the European Union] relative to other parties"; and fourth, the United States disliked "[r]ules that purport to change treaty commitments through decisions of the parties rather than through the proper amendment procedure". ${ }^{65}$ Regrettably, the United States did not bring any fresh proposals to the negotiating table for discussion. In fact, the Bush administration set aside its Cabinet-level review of the alternatives to the Kyoto Protocol in the wake of the 11 September terrorist attacks and while carrying out the United States diplomatic and military response. Among the 160 governments represented at Marrakech, the United States stood alone as the only one explicitly opposed to the Protocol. Ironically, on 9 November 2001, the very day that agreement was reached in Marrakech on the Kyoto Protocol, the Energy Information Administration of the United States Department of Energy reported that heat-trapping CO2 emissions in the United States increased by 3.1 percent, the largest increase since the mid-1990s. ${ }^{66}$

On 14 February 2002 President Bush offered for the first time detailed insight into his plan for combating global warming. The essence of the Bush plan relies upon curtailing greenhouse gas emissions by reliance upon voluntary efforts and market forces, rather than government regulation. The need for such a United States strategy was prompted by growing criticism and concern that the United States was shirking its responsibility for dealing with a perplexing global problem by disavowing the Kyoto Protocol in March 2001.

According to the Bush administration, this plan is motivated by the adverse consequences that mandatory limits under the Kyoto Protocol would impose on United States industry, purportedly leading to $\$ 400$ billion in losses for United States industry and the elimination of 4.9 million American jobs. Under the Bush plan, the key to curbing the serious threat of global warming is the investment of billions of dollars into research, new technology, and tax incentives to promote voluntary reductions, as opposed to the imposition of mandatory regulatory target levels of emissions. In fact, in the Bush

65 These reasons were asserted in the United States closing statement to the conference. See Paula Dobriansky, Under Secretary of State for Global Affairs, "Closing Statement to the Seventh Session of the Conferences of Parties (COP-7) Marrakech, Morocco, November 9, 2001, $<$ http: / / www.state.gov /g / ... /index.cfm?docid=6050\&CFNoCache=TRUE\&printfriendly=tru $>$.

Pianin "160 Nations Agree to Warming Pact", (11 November 2001) Washington Post A01. 
administration's 2003 budget proposal, the United States would spend $\$ 4.5$ billion, more than any other state, to address the problem of global warming. ${ }^{67}$

At the heart of the Bush administration's plan is a "cap and trade" system that would impose mandatory ceilings on industry to reduce the output of three major air pollutants. Permits would be assigned for each ton of pollution. By cutting emissions, firms would save up these permits for use at a later date or to trade with other businesses, emissions covered by the scheme would be sulfur dioxide, blamed for acid rain; nitrogen oxides, found in smog; and mercury, blamed for inflicting serious health problems on children. No limits are set for carbon dioxide emissions, however, which is the most potent of the greenhouse gases. The Bush climate change policy sets a goal to cut greenhouse gas intensity by eighteen percent over the next ten years, by setting up a voluntary scheme to reduce emissions. It expands the current voluntary emissions reduction program under section 1605(b) of the Energy Policy Act 1992 to provide credit to those firms that reduce emissions.

Supporters of the Bush plan assert that it acknowledges the scientific uncertainties of climate change and the need for more information and advanced technologies to study the issue. Their fundamental point is that before the United States mandates reductions in carbon dioxide that drastically raise the price of energy, adversely impact the American economy, and thus put the United States at an internationally comparative disadvantage, scientists and policy makers must do more homework. The Bush voluntary program highlights the administration's resolve to do just that by sustaining economic growth, while conducting further research on global warming. At the same time, Bush supporters argue that such economic growth advances innovations that lead to clear air and more efficient technologies that in the long run will drive down levels of greenhouse gases. ${ }^{68}$

The Bush plan preserves the status quo. It permits the United States to continue to emit carbon dioxide and other greenhouse gases at the same rate it has done since 1990. While this occurs, however, there is the pledge of $\$ 4.6$ billion in incentives and tax credits over the next five years for research and for fostering voluntary reductions by utilities and manufacturers. In his speech announcing the plan, President Bush asserted that such an approach would reduce emissions from present levels by two-thirds to three-quarters over the next decade.

Critics have been quick to score the Bush plan as a failure to act decisively to slow the growth in greenhouse gas emissions. The plan only puts off making hard decisions for

67 Eric Pianin "Bush Unveils Global Warming Plan", (15 February 2002) Washington Post, A9.

68 Charlie Coon, "President Bush's Climate Change Proposal", Heritage Foundation WebMemo 6 March 2002, <sysiwyg:/ / 66/ http: / / www.heritage.org/shorts/20020306global.html>. 
another 10 years, and in the process permits the situation to grow worse, thereby complicating any real solutions in the long term. Rather than set limits on carbon dioxide emissions, the administration coined a new term-"greenhouse gas intensity"-which is defined as the ratio of carbon dioxide emissions to gross domestic product. The administration's avowed non-mandatory goal is to cut this figure by eighteen percent over the next decade. Critics assert that this allows the Bush administration to pretend setting goals at reducing emissions, while actually doing no such thing. So long as GNP grows, so too can greenhouse gas emissions, though with a reduction in the ratio between the two. ${ }^{69}$

The Bush plan comes in the wake of new evidence that the global warming trend of the past several years is continuing. For the United States, the National Climatic Data Center has calculated that the average national temperature for November 2001-January 2002 was 39.94 degrees Fahrenheit, 4.3 degrees above the 1895-2002 average. Globally, the World Meteorological Organization calculated that 2001 was the second warmest year on Earth since 1860, when systematic record-keeping began. Nine of the ten warmest years have occurred since 1990, the warmest being 1998. The next two warmest were 2001 and 1997, respectively. More ominously, recent events in the polar south have clearly indicated major disruptions in the local environment. In March 2002, a 3,250 square kilometer area of ice estimated to weigh 500 billion tonnes broke off the Antarctic continent's Larsen B ice shelf. This collapse is believed to have dumped into the Southern Ocean more ice than all the other icebergs since 1950 combined. Moreover, a second monster iceberg has been detected as being in the process of breaking off the Southern Admunsen Sea. Iceberg B22, as it is called, is more than 64 kilometers ( 40 miles) wide and 85 kilometers ( 53 miles) long, and covers an area approximating 5,500 square kilometers. ${ }^{70}$ The belief by scientists is that such ice retreats are attributed to global warming in the region, particularly around the Antarctic Peninsula. As the circumpolar waters warm, the ice sheets fracture, and collapse. As the ice shelves collapse, and the ice melts, sea levels will rise. Of greatest concern is the Western Antarctic Ice Sheet, which is grounded on muddy ocean floor, not a solid

69 According to the United States Energy Information Administration, the calculation called "greenhouse gas intensity" declined by an average of 1.6 percent a year over the past 10 years, while emissions have steadily increased and the effects for global warming have become more apparent. The administration's plan would permit continuation of this trend. Carbon dioxide emissions by United States industry are presently put at 15 percent above 1990 levels, and critics calculate that by 2020, "the absolute levels of emissions could reach as high as 43 percent above 1990 level", given the assumptions that targeted goals and voluntary reductions are actually implemented. See Joseph Kay, "Bush announces new global arming plan: a Valentine's Day gift for energy corporations", World Socialist Web Site, 23 February 2002: <http:/ / www.wsws.org/ articles / 2002/ feb2002/warm-f23.shtml> .

70 John Vidal "Antarctica sends 500 billion tonne warning of the effects of global warming, 22 March 2002 The Guardian <http:/ / eductation.guardian.co.uk/Print/0,3858,4377526,00.html>. 
subglacial continental rock foundation. Should the entire West Antarctic Ice Sheet melt, sea levels worldwide could rise five to six meters. In the past, sea level rise attributed to global warming has been more theoretical speculation than scientific fact. The recent collapse of these ice shelves in Antarctica clearly suggests that greenhouse-induced global warming may be taking a real toll in the first years of the twenty-first century.

In the end, the key question that remains is just how effective the Kyoto instrument can be when the United States, the world's largest emitter of greenhouse gases, opts out of the treaty's legal obligations. The future remains murky, not only about the efficacy of the Kyoto Protocol in controlling greenhouse gas emissions and checking global warming, but also about how severely United States non-participation will impact upon that process. But this much is certain. In the short term, United States national interests might appear best served by this go-it-alone strategy. In the long term, however, one must wonder about whether the same can be said for global interests. Finally, it is worth noting that international legal rules ultimately reflect the degree of political commitment by governments toward attaining their stated environmental objectives. Unless genuine political commitment exists for the goal of reducing the use of fossil fuels--in the United States, in other developed countries, and in developing countries--international law, including the Kyoto Protocol, will not be effective in addressing climate change. While this does not suggest that the development of law and policy must stagnate while waiting for the United States to demonstrate the necessary political commitment, it does mean that multilateral efforts to create the best law and policy response must continue. These efforts in themselves can help to generate additional political commitment, as they demonstrate what can be achieved through the convictions of an international civil society, notwithstanding the unilateral policy of a recalcitrant economic superpower. 
